\title{
Influência da tonicidade e local da ruptura na palavra em adolescentes $\mathrm{e}$ adultos gagos e fluentes***
}

\author{
Tone influence and word boundaries in stuttering and fluent \\ adolescents and adults
}

Fabiola Staróbole Juste*

Claudia Regina Furquim de Andrade**

*Fonoaudióloga. Doutora em Semiótica e Linguística Geral pela Faculdade de Filosofia, Letras e Ciências Humanas da Universidade de São Paulo (USP). Fonoaudióloga do Departamento de Fisioterapia, Fonoaudiologia e Terapia Ocupacional da Faculdade de Medicina da USP. Endereço para correspondência: R. Cipotânea, 51 São Paulo - SP - CEP 05360-160. (fjuste@usp.br).

**Fonoaudióloga. Professora Titular do Departamento de Fisioterapia, Fonoaudiologia e Terapia Ocupacional da Faculdade de Medicina da USP.

***Trabalho Realizado no Laboratório de Investigação Fonoaudiológica da Fluência, Funções da Face e Disfagia da Faculdade de Medicina da USP.

Artigo Original de Pesquisa

Artigo Submetido a Avaliação por Pares

Conflito de Interesse: não

Recebido em 07.05.2010.

Revisado em 20.08.2010.

Aceito para Publicação em 20.08.2010.

\section{Abstract}

Background: this study examines the linguistic features that may influence the occurrence of speech boundaries in fluent and stuttering individuals. Aim: the study seeks to examine the influences of tone and position in a word on the occurrence of speech boundaries in stuttering and fluent adolescents and adults. Method: one hundred and twenty individuals took part in this study, both male and female, with ages between 12.0 and 49.11 years old, and were divided into 4 groups: research group 1 (RG1), with 30 stuttering adolescents; research group 2 (RG2), with 30 stuttering adults; control group 1 (CG1), with 30 fluent adolescents; and control group 2 (GC2), with 30 fluent adults. Speech samples containing 200 fluent syllables were collected. In the speech samples, the broken syllables were analyzed according to their tone (unstressed, pre-stressed or stressed) and according to the position in the word (initial, middle or final syllable). Results: for tone, there was no statistically significant difference in the number of boundaries between the evaluated tones for any of the tested groups. For the location of the broken syllable, there was a predominance of broken syllables in the initial position of words for the stuttering groups of speakers. For the fluent groups, the ruptures were more frequent in the final syllable. Conclusion: the results of this study reinforce the theory that broken speech is mainly a consequence of slow phonological coding and a corresponding slowness in the building up and recovery of the phonetic plan. Key Words: Speech, Language and Hearing Sciencies; Stuttering; Fluency.

\section{Resumo}

Tema: aspectos linguísticos que podem influenciar a ocorrência de rupturas na fala de indivíduos gagos e fluentes. Objetivo: verificar a influência da tonicidade e da posição dentro da palavra na ocorrência de rupturas de fala em adolescentes e adultos gagos e fluentes. Método: participaram do estudo 120 indivíduos, de ambos os sexos, com idades entre 12.0 a 49.11 anos, divididos em 4 grupos: grupo de pesquisa 1 (GP1) - 30 adolescentes gagos; grupo de pesquisa 2 (GP2) - 30 adultos gagos; grupo controle 1(GC1) - 30 adolescentes fluentes; grupo controle 2 (GC2) - 30 adultos fluentes. Foram coletadas amostras de fala contendo 200 sílabas fluentes. Nas amostras de fala, as sílabas rompidas foram analisadas quanto à sua tonicidade (átona, pré-tônica ou tônica) e quanto ao local da ruptura na palavra (sílaba inicial, medial ou final). Resultados: quanto à tonicidade, para todos os grupos testados, não houve diferença estatisticamente significante no número de rupturas entre as tonicidades avaliadas. Em relação ao local da ruptura na sílaba, para os grupos de falantes gagos, houve predominância de rupturas na sílaba inicial das palavras e para os grupos fluentes, as rupturas foram mais frequentes na sílaba final. Conclusão: os resultados desse estudo reforçam a teoria de que as rupturas de fala decorrem principalmente da lentidão na codificação fonológica e na habilidade de construir e recuperar o plano fonético.

Palavras-Chave: Fonoaudiologia; Gagueira; Fluência. 


\section{Introdução}

During the last decades, studies have been performed that have examined the relationship between fluency and the metric structure of speech, in many cases establishing an association between stuttering events and syllable tone. For a better understanding of this relationship, it is necessary to define some of the specific terms of this body of work.

For Snow1-2, prosody (frequency, duration and intensity of emissions) may be considered a suprasegmental phonologic feature. Prosodic shifts may be considered the first perceptual "clues" through which a child acquires fundamental phonological and syntactic features.

The evaluation of the use of syllabic stress has been proposed as a means of diagnosis (i.e., the analysis of phonologic metrics) of the changes in lexical levels produced by metric impact (i.e., omission of syllables and vowel extensions). In phonologic metrics, syllables are classified as strong (stressed) or weak (non-stressed/ unstressed). The syllables of a word and the words in a sentence tend to alternate between strong and weak syllables, creating a basic rhythm for words and phrases3

For Hubbard4, speech rhythm refers to the oral language cadence or melody that is established by tone and speed standards. According to this author, speakers use three hierarchical levels of structure to produce rhythm: words, phonological phrases and intonation phrases. Within this structure, words and their tone are considered to be determined by their syllables (stressed and unstressed).

In the literature, researchers have investigated the connection between stuttering and tone, showing very divergent results. These differences may be the product of methodological diversity; some studies were performed with previously balanced word lists, whereas others were based on spontaneous speech.

Van Riper5 points out that ruptures are more likely to occur in stressed syllables due to a failure in the coordination of certain muscle contractions that should occur in a simultaneous way in synchrony with the stressed syllable nuclei.

According to Wingate6, as also emphasized by Howell et al.7, the relationship between stuttering and word tone do not seem to have as much influence for children. These authors observe that, in English, the stress is related to the kind of word. Functional words (as opposed to content words) are not usually stressed. These authors note that tone seems not to have much influence in the production of speech ruptures in children because children show ruptures mainly in functional words, which are less stressed.

A study conducted with 20 adults (ten stutterers and ten fluent subjects) to research the occurrence of ruptures in their relation to word familiarity and to the stress pattern of the word indicated statistically relevant differences only for frequency; less familiar words showed a greater number of ruptures. The authors did not find significant results concerning the occurrence of stuttering in relation to syllable tone8.

Natke et al.9 conducted a study with 40 Germanspeaking stuttering adults, and the results indicated that ruptures occurred more frequently with stressed syllables than with unstressed syllables. In another study10, this time conducted with 22 German-speaking stuttering children, the results obtained were similar to the study of adults; speech ruptures were more frequent in stressed syllables.

In another study4, the occurrence of ruptures was investigated with relation to their situation in the word and with relation to tone. For tone, the results indicated that there was no significant difference between the occurrence of ruptures in unstressed or stressed syllables. The results were significant only concerning the place of rupture, for which it was observed that the great majority of ruptures occur in the initial syllable of the word.

Independent of this line of theoretical inquiry, a number of authors agree that ruptures are more frequent at the beginning of words6,9-16. A few studies report the occurrence of ruptures in other word positions, such as, for example, in the final syllable. Studies that approach this theme involve mainly reports of individual cases due to the limited occurrence of these phenomena, which are usually connected with individuals with severe phonological impairment, phonological syndromes or neurological sequelae17-18.

Bloodstein13 estimated that approximately 90\% of ruptures occur in the first sound or the first syllable of the word.

In linguistic terms, from the 1970s onward, the syllable was consistently accepted as a phonologic unit20, and, furthermore, it was considered the fundamental structure in the hierarchical organization of phonological levels21. The syllabic unit has been understood to be very important for the development of the linguistic system as a whole.

According to Levelt22, the syllable is the basic unit of the word's phonetic planning, which, 
according to Pereira16, explains the fact that disfluencies occur predominantly in the initial syllable of a word. In a study conducted with 21 stuttering adults, the author observed that the ruptures occurring at the word level occurred predominantly in syllables at the initial position. The author proposes that, according to the hypothesis of Postma and Kolk23, rupture occurs when the speaker tries to restart the production of the linguistic structure after a difficulty is found.

In relation to this existing literature, this study seeks to further determine the influences of tone and position within a word in the occurrence of speech ruptures in stuttering and fluent adolescents and adults.

\section{Method}

The study's processes of selection and evaluation followed the pertinent ethical guidelines, including those of the Parecer da Comissão de Ética (Ethical Commission Report) (CAPPesq HCFMUSP $\left.\mathrm{n}^{\circ} 0823 / 07\right)$. The study was preceded by the signing of the Termo de Consentimento Livre e Esclarecido (Free and Clear Terms of Consent) by the participants or (in the case of adolescent individuals) by their guardians .

\section{Participants}

One hundred and twenty stuttering and fluent individuals paired by gender and age who were residents of São Paulo proper and of greater São Paulo took part in this study. All participants agreed to the procedures proposed of this research by signing an agreement of consent.

The participants in this study were divided into four groups:

. research group 1 (RG1), which was composed of 30 adolescents with ages between 12.0 and 17.11. There were 19 males and 11 females with a diagnosis of stuttering without any other associated communication, neurological or cognitive shortfall; . research group 2 (RG2), which was composed of 30 adults with ages between 18.0 and 44.11 years. There were 24 males and 6 females with a diagnosis of stuttering without any other associated communication, neurological or cognitive shortfall; . control group 1 (CG1), which was composed of 30 adolescents paired with the RG1 for gender and age and without any complaint of stuttering or any other associated communication, neurological or cognitive shortfall;

. control group 2 (CG2), which was composed of 30 adults paired with the RG2 for gender and age and without any complaint of stuttering or any other associated communication, neurological or cognitive shortfall.

\section{Inclusion criteria for RG1 and RG2:}

- participants showed a fluency profile outside the reference values corresponding to their age24;

- participants had received 11 points or more (for the adolescents) or 18 points or more (for adults) (i.e., severity equivalent to at least "mild") on the Stuttering Severity Instrument 3 (SSI-3) assessment25.

The criteria for the inclusion of the participants in CG1 and CG2 were:

- participants had shown a fluency profile equivalent to the reference values corresponding to their age24;

- participants had received a total of 10 points (for adolescents) or 17 points (for adults) (i.e., severity equivalent to "very mild") or less on the SSI-3 assessment25.

\section{Material}

For the recording and analyzing of the speech samples, we used a Sony Digital DCR-SR85 camera attached to a tripod, a Dell Studio Hybrid microcomputer and an HP Mini 1120BR Netbook.

The speech samples were collected and analyzed according to the Protocolo do Perfil da Fluência26 and by means of the Stuttering Severity Instrument 3 assessment (SSI-3)25 in order to determine the stuttering severity in RG1 and RG2.

\section{Procedure}

\section{Collection of speech samples}

To obtain speech samples, the methodology proposed by Andrade26 was adopted. A picture was shown to participants and they were given the following direction: "please look at this picture and tell me all you'd like to tell me about it". Speech was interrupted only by questions and/or comments in the cases in which there was a need to encourage the production of speech in order to obtain a total of 200 fluent syllables (the number of fluent syllables needed for the analysis of the sample). A minimum of 5 minutes was established as the time allotted for each collection. 


\section{Analysis of speech samples}

After the collection of the participants' speech samples, the samples were transcribed and characterized according to rupture typologies, according to broken syllable tone and according to the position of rupture in the word. The ruptures were numbered in order to make the identification and the application of the adopted procedures of analysis easier.

\subsection{Characterization of rupture typology}

The ruptures were classified and analyzed according to the Fluency Profile Protocol26 and divided into:

2.1.1. Common ruptures: hesitations, interjections, revisions, unfinished words and repetitions of words, segments and phrases;

2.1.2. Stutter ruptures: repetitions of sounds and syllables, extensions, blocks, pauses and intrusions.

After the analysis of rupture typology, the typologies whose rupture occurred inside a word were separated (i.e., sound repetition, syllable repetition, block and extension). For these ruptures, the procedures mentioned in items 2.2 and 2.3 were applied.

\subsection{Broken syllable tone characterization}

The syllables that showed ruptures were analyzed according to tone. When the analysis was performed at the word level, the typologies considered were sound repetition, syllable repetition, extension and block. For each rupture, one broken syllable tone was identified (whether an unstressed syllable, a pre-stressed [in the case of trisyllabic and polysyllabic words] syllable, or a stressed syllable).

\subsection{Characterization of the position of rupture in the word}

This characterization refers to the word unit, and thus only the ruptures that occur inside the word (and not between words) were analyzed. For this reason, this analysis was restricted to ruptures of the types sound repetition, syllable repetition, extension and block. For each event, we analyzed at which syllable the rupture occurred: the initial, the middle (in the case of trisyllabic and polysyllabic words), or the final.
Statistical Analysis

For statistical analysis of the data, the analysis of variance test (ANOVA) was used, with a significance level of $5 \%$.

\section{Results}

Table 1 shows the results obtained for the adolescent groups with regard to the distribution of ruptures that were dependent on syllable tone. The results indicated that, for RG1, there was no statistically significant difference between ruptures in unstressed, pre-stress and stressed syllables $(F(2.87)=1.14, p=0.323)$. For CG1, the results shown on Table 1 show that the ruptures occurred mainly at unstressed and stressed syllables, with no statistically significant difference between those two tones $(\mathrm{F}(2.87)=2.14, \mathrm{p}=0.124)$.

According to these results, it can be observed that, taking the numerical differences of the occurrence of ruptures among the groups into account, stuttering and fluent adolescents behaved in the same way. In other words, for both groups, there was no predominance of the occurrence of ruptures in a specific tone.

Moreover, Table 1 shows the results obtained for the adult groups. The results indicated that, for RG2, the ruptures were concentrated mainly in the unstressed and stressed syllables, without any statistically significant difference between those two tones $(F(2.87)=2.55, p=0.083)$. For CG2, the results shown in Table 2 show that there was no occurrence of ruptures in pre-stressed syllables and that the distribution of ruptures between stressed and unstressed syllables did not show any statistically significant difference $(F(2.87)=1.53, p=0.132)$.

These results indicate a similarity between the adolescent and adult groups. Without considering the numeric differences of the ruptures occurring between the stuttering and fluent groups, none of the analyzed groups showed a predominance of ruptures in a specific tone.

In Table 2 we can observe that, concerning the place of rupture in the word, RG1 showed an expressively significant number of initial syllable ruptures; that difference was statistically significant when compared to the other positions $(\mathrm{F}(2.87)=$ 50.18, $\mathrm{p}<0.001$ ). Moreover, Table 3 shows that, when compared with CG1, there was a statistically significant predominance of ruptures in final syllables compared with the ruptures in initial syllables $(\mathrm{F}(2.87)=4.91, \mathrm{p}=0.003)$. Ruptures in middle syllables were not observed for this group. 
Table 3 shows that RG2 showed a predominance of ruptures in the initial syllable, and this difference was statistically significant when compared with the other positions $(\mathrm{F}(2.87)=33.80$, $\mathrm{p}<0.001)$. Table 3 indicates that CG2 showed a larger number of ruptures in the final syllable position, and this difference was statistically significant when compared with ruptures in the initial syllable $(\mathrm{F}(2.87)=7.88, \mathrm{p}<0.001)$. Ruptures in middle syllables were not observed for this group.

TABLE 1. Analysis of the relation between groups of adolescents (RG1 and CG1) and adults (RG2 and CG2) with regard to broken syllable tone.

\begin{tabular}{l|ccc|ccc|ccc}
\hline & \multicolumn{3}{|c|}{ Unstressed } & \multicolumn{3}{c|}{ Pre-stress } & \multicolumn{3}{c}{ Stressed } \\
\hline RG1 & total & Average & SD & total & Average & SD & total & Average & SD \\
CG1 & 89 & 2.96 & 2.12 & 85 & 2.83 & 2.82 & 114 & 3.8 & 3.01 \\
RG2 & 9 & 0.3 & 0.65 & 0 & 0 & 0 & 6 & 0.2 & 0.55 \\
CG2 & 186 & 6.2 & 6.80 & 112 & 3.73 & 2.85 & 207 & 6.9 & 6.55 \\
\hline
\end{tabular}

Key: SD - Standard Deviation.

TABLE 2. Analysis of the relation between groups of adolescents (RG1 and CG1) regarding the place of rupture in the word.

\begin{tabular}{l|ccc|ccc|crc}
\hline & \multicolumn{3}{|c|}{ Initial Syllable } & \multicolumn{3}{c|}{ Middle Syllable } & \multicolumn{3}{c}{ Final Syllable } \\
\hline \multirow{3}{*}{ RG1 } & total & average & SD & total & average & SD & total & average & SD \\
CG1 & 266 & 8.86 & 6.37 & 12 & 0.4 & 0.81 & 15 & 0.5 & 1.04 \\
\hline
\end{tabular}

Key: SD - Standard Deviation.

TABLE 3. Analysis of the relation between groups of adults (RG2 and CG2) with regard to the place of rupture in the word.

\begin{tabular}{l|ccc|ccc|ccc}
\hline & \multicolumn{3}{|c|}{ Initial Syllable } & \multicolumn{3}{c|}{ Middle Syllable } & \multicolumn{2}{c}{ Final Syllable } \\
\hline & total & average & SD & total & average & SD & total & average & SD \\
RG2 & 401 & 13.36 & 9.64 & 46 & 1.53 & 2.64 & 71 & 2.36 & 4.02 \\
CG2 & 5 & 0.16 & 0.37 & 0 & 0 & 0 & 12 & 0.4 & 0.56 \\
\hline
\end{tabular}

Key: SD - Standard Deviation.

\section{Discussion}

According to the results shown above regarding syllable tone, for both stuttering and fluent adolescents and adults the distribution of speech ruptures was the same for unstressed, prestressed and stressed syllables. The speech ruptures of stuttering adolescents and adults were distributed in an equivalent manner for the three possibilities of tested tone (unstressed, prestressed and stressed), and those results were compliant with the results of other studies testing the same issues4,6,8,27. As for the fluent adolescents and adults, ruptures were equally distributed between unstressed and stressed syllables because no occurrence of ruptures in pretonic syllables was observed.
Although the results of the present study indicate that there was no direct influence of tone on the occurrence of speech ruptures, the literature contradicts these results. Studies can also found that suggest that speech ruptures are more frequent in stressed syllables5,9-10.

As we already observed in the introduction, this controversy of results might be caused by a methodological diversity, given that some studies have been conducted with previously balanced word lists, and others have been conducted with spontaneous speech (as is the case with the present study). 
Apart from this methodological diversity, the stress pattern of languages is also diverse, a fact that makes it difficult to compare results between studies conducted in different languages.

The results suggest that, for the participants in this study, syllable tone seems not to influence the occurrence of speech ruptures. The factor that seems to exert the strongest influence on the occurrence of ruptures is position in the word. These results are similar to those produced by Hubbard8, who found no evidence of the influence of tone on speech ruptures. For Hubbard, the influence of the place of rupture in the word was strongly marked, occurring most frequently in initial syllables.

The results of the present study also indicate that the great majority of speech ruptures occurred for stuttering speakers in the initial syllables of words, results that agree with the conclusions of several studies4,6,9-16,28. Ruptures occurring in the beginning of the word serve as evidence of the difficulty in initiating the production of a linguistic structure10,13.

The theory proposed by Postma and Kolk23 is based on the notion that difficulties in phonological code and in the ability to build and recover a phonetic plan can result in speech ruptures. According to this theory, people that stutter seem to show a slow pace in the phonological coding process, increasing the chance of errors in the selection of the target phoneme. When those mistakes of phonetic plan are identified, a speaker will repair them automatically in the speech process itself by producing another similar segment, using for this the same articulating position or close variations of that position. The perception of a mistake and the process of repairing that mistake produce the speech sound reiterations and interruptions that characterize ruptures34. The rupture in the initial position of words occurs when the speaker tries to restart the production of the linguistic structure after the difficulty has been discovered16.

As for the occurrence of ruptures in the middle position of words, this seems to be a feature specific to stuttering, since, in this study, those ruptures were found only in the samples of stuttering participants. A study conducted with stuttering and fluent children speakers of Brazilian Portuguese also supports this finding; in that study, only the stuttering children showed speech ruptures in the middle position of words30.

The results indicate that, unlike the ruptures of the groups of stuttering speakers, the speech ruptures of fluent speakers were more frequent in the final syllable of words. A possible explanation for this might be that the recovery process of a unit motor program starts a little before the expression of the unit that comes before. Therefore, when the speaker is articulating a unit, it means that the motor program of the following unit is already available to the one that is being articulated. For fluency to be reached, the mechanism used by the speaker is to extend the final part of the previous word16,22. The use of this mechanism was observed for stuttering speakers as well as for fluent speakers in this study.

The occurrence of extensions and their situation in a word deserves to be analyzed with more detail because these features of speech varied significantly between the groups of stutters and the groups of fluent subjects.

In this study, extensions appeared in two distinct ways in the speech samples of participants: extensions of phonemes situated in the initial and middle syllables of words and the extension of the last sound of the last syllable of a word. The results showed that only the stuttering speakers showed this kind of extension in a word, an extension responsible for breaking the lexical unit, which is the main characteristic of those disfluencies considered to be stutters.26 For fluent speakers, extensions occurred exclusively in the last phoneme of the final syllable of words. In this case, unlike extension inside of a word, the extension of the final sound of a word resembles the disfluency of hesitation, a commonly used strategy to make the coarticulation between words easier16,22.

\section{Conclusion}

The general objective proposed by this study was to examine the influence of tone and position inside a word in the occurrence of speech ruptures in stuttering and fluent adolescents and adults.

With regard to tone, the results indicated that speech ruptures were distributed in an equivalent way among unstressed, pre-stressed and stressed syllables for the stuttering speakers and among unstressed and stressed syllables for the fluent speakers, suggesting that the factor of tone did not exert any influence in the occurrence of speech ruptures for the participants.

With regard to the place of rupture in a word, it was observed that the stuttering speakers experienced the great majority of their speech ruptures in the initial syllables of words. This finding is broadly equivalent to the findings of other national and international research on these 
questions. For the fluent speakers, there was a predominance of ruptures in the final syllable of words, which exclusively took the form of extensions.

The differences between the groups were made clear by the occurrence of ruptures in the middle position of words and of extension in the initial syllable; both of these results were found only in the samples of stuttering speakers.
In general, the results of this study reinforce the theory that speech ruptures are results mainly of the slow pace of phonological coding and a corresponding slowness in the building up and recovery of the phonetic plan. Therefore, all speakers are subject to the presentation of ruptures in speech; the differential factor between stutterers and fluent speakers is the frequency with which those ruptures occur and the question of the possibility of prompt recovery of the system, an ability exhibited only by fluent speakers.

Acknowledgements: this research was financed by FAPESP (process 2007/03702-5) in form of a Post-Doctoral Fellowship.

\section{References}

1. Snow D. Prosodic markers of syntactic boundaries in the speech of 4-year-old children with normal and disordered language development. Journal of. Speech, Language and Hearing Research. 1998;(41):1158-70.

2. Snow D. A Prominence account of syllable reduction in early speech development: The child's prosodic phonology of tiger and giraffe. Journal of. Speech, Language and Hearing Research. 1998;(41):1171-84.

3. Velleman SL, Shriberg LD. Metrical analysis on the speech of children with suspected developmental apraxia of speech. Journal of Speech, Language, and Hearing Research. 1999;(42):1444-60.

4. Hubbard CP. Stuttering, stressed syllables, and word onsets. Journal of Speech, Language, and Hearing Research. 1998;(41):802-8, .

5. Van Riper C. The nature of stuttering. New Jersey: Prentice-Hall; 1982.

6. Wingate ME. Stutter events and linguistic stress. Journal of Fluency Disorders. 1984;(9):295-612.

7. Howell P, Au-Yeung J, Sackin S. Exchange of stuttering from function words to content words with age. Journal of Speech, Language, and Hearing Research. 1999;(42):34554.

8. Hubbard CP, Prins D. Word familiarity, syllabic stress pattern, and stuttering. Journal of Speech, Language, and Hearing Research. 1994;(37):564-71.

9. Natke U, Grosser J, Sandrieser P, Kalveram KT. The duration component of the stress effect in stuttering. Journal of Fluency Disorders. 2002;(27):305-18.

10. Natke U, Sandrieser P, Ark M, Pietrowsky R, Kalveram KT. Linguistic stress, within-word position, and grammatical class in relation to early childhood stuttering. Journal of Fluency Disorders. 2004;(29):109-22.

11. Ratner NB. Language complexity and stuttering in children. Topics in Language Disorders. 1995;3(15):3247.
12. Ratner NB. Performance or capacity, the model still requires definitions and boundaries it doesn't have. Journal. of Fluency Disorders. 2000;(25):337-46.

13. Bloodstein O. Incipient and developed stuttering as two distinct disorders - Resolving a dilemma. Journal of Fluency Disorders. 2001;(26):67-73.

14. Yairi E. Disfluency characteristics of childhood stuttering. In: Curlee e Siegel (orgs.) - Nature and treatment of stuttering: new directions. Boston: Allyn\&Bacon; 1997. p. 49-78.

15. Conture EG. Stuttering: its nature, diagnosis, and treatment. Needham Heights: Allyn \& Bacon; 2000.

16. Pereira MMB. Análise linguística da gagueira. São Paulo: AM3 Artes; 2003.

17. Stansfield J. Word-final disfluencies in adults with learning difficulties. Journal of Fluency Disorders. 1995;(20):1-10.

18. Van Borsel J, Van Coster R, Van Lierde K. Repetitions in final position in a nine-year-old boy with focal brain damage. Journal of Fluency Disorders. 1996;(21):137-46.

19. Mcallister J, Kingston M. Final part-word repetitions in school-age children: two case studies. Journal of Fluency Disorders. 2005;(30):255-67.

20. Bisol L. A sílaba e seus constituintes. In: Neves MHM (org). Gramática do Português Falado. Volume VII. Campinas: Humanitas. Ed. Unicamp; 1999.

21. Gierut JA. Syllable onset: clusters and adjuncts in acquisition. Journal of Speech, Language and Hearing Research. 1999;(42):708-26.

22. Levelt WJM. Speaking - from intention to articulation. Cambridge: MIT Press; 1989.

23. Postma A, Kolk H. The covert repair hypothesis: Prearticulatory repair processes in normal and stuttered disfluencies. Journal of. Speech and Hearing Research. 1993 (36):472-87. 
24. Andrade CRF: Perfil da Fluência da Fala: Parâmetro comparativo diferenciado por idade para crianças, adolescentes, adultos e idosos [CD-ROM]. Barueri: Pró Fono; 2006.

25. Riley GD. A stuttering severity Instrument for children and adults. Austin: Pro-Ed; 1994.

26. Andrade CRF. Protocolo para a avaliação da fluência da fala. Pró-fono Revista de atualização científica. 2000;2(12):131-4.

27. Weiner AE. Stuttering and syllable stress. Journal of Fluency Disorders. 1984;(9):301-5.
28. Huinck WJ, Van Lieshout PHHM, Peters HFM, Hulstijn W. Gestual overlap in consonant clusters: effects on the fluent speech of stuttering and non-stuttering subjects. Journal of Fluency Disorders. 2004;(29):3-25.

29. Andrade CRF. História natural da gagueira - estudo III: vocabulário, fonologia e pragmática. Pró-fono Revista de atualização científica. 2002:14(3):371-82.

30. Juste F. A influência dos aspectos gramaticais e prosódicos na fala de crianças fluentes e gagas [tese]. São Paulo(SP): Universidade de São Paulo - Faculdade de Filosofia, Letras e Ciências Humanas; 2006. 